VERTAISARVIOITU

KOLLEGIALT GRANSKAD

PEER-REVIEWED

www.tsv.fi/tunnus

\title{
ESIMIEHEN JA TYÖNTEKIJÄN VUOROVAIKUTUSSUHDE - HEIJASTUMIA MUUTTUVAAN TYÖELÄMÄÄN
}

\author{
Riitta Forsten-Astikainen, Oulun yliopisto, Kerttu Saalasti \\ Instituutti, Mikroyrittäjyyskeskus MicroENTRE \\ Susanna Kultalahti, Vaasan yliopisto, Johtamisen yksikkö, \\ Henkilöstöjohtaminen
}

\begin{abstract}
Työelämässä meneillään oleva murros edellyttää ihmisiltä yhä enemmän vuorovaikutustaitoja; työt pirstaloituvat (silpputyö) ja siirtyvät verkostoihin, digitalisoituminen, monimuotoistuminen monikulttuurisuuden ja uusien työntekijäsukupolvien myötä ja entinen osaaminen kohtaavat huomattavia muutospaineita. Erityisesti esimiehillä on merkittävä rooli, ja heidän vuorovaikutuskyvykkyytensä on avaintekijä muutoksissa, arjen sujumisessa, tuottavuuden ja työmotivaation ylläpidossa sekä työyhteisön työhyvinvoinnin ja työilmapiirin kehittymisessä.

Artikkelissa tutkitaan eri työntekijäryhmien kokemuksia vuorovaikutussuhteesta esimiehen kanssa sekä suhteen vaikutuksia työn imuun, yksilön ja yksikön osaamiseen ja yksikön suoriutumiseen sekä joustavuuteen. Tutkimuksen perustana on LMX-teoriaan pohjautuva käsitys esimiehen ja alaisen välisestä suhteesta. Aineisto on kerätty 4500 vastaajalta 93 pk-yrityksestä eri toimialoilta Suomessa ja analysoitu kvantitatiivisesti. Tutkimus liittyy Vaasan yliopiston ja Lappeenrannan teknillisen yliopiston 2015-2016 toteuttamaan HERMES-projektiin.

Tutkimuksen keskeisin havainto liittyy työsuhteen tyyppiin ja työntekijän kokemukseen vuorovaikutuksen tasosta. Määräaikaisessa työsuhteessa olevat työntekijät arvioivat vuorovaikutuksen esimiehen kanssa parhaimmaksi verrattuna vakituisessa ja vuokratyösuhteessa oleviin. Löydös on yllättävä, ja kertoo vuorovaikutussuhteen merkityksellisyydestä ja uniikista kokemisesta. Vuorovaikutussuhteet erosivat myös sukupuolen ja esimiesaseman suhteen ja työntekijän asema vaikutti vuorovaikutussuhteen kokemisessa.
\end{abstract}

Avainsanat: esimiestyö, LMX-teoria, osaaminen, työsuhteen tyyppi, vuorovaikutus, vuorovaikutteinen johtaminen

Kirjoittajien yhteystiedot:
Riitta Forsten-Astikainen
riitta.forsten-astikainen@oulu.fi
Susanna Kultalahti
susanna.kultalahti@univaasa.fi

\section{JOHDANTO}

Työelämä on täynnä vuorovaikutusta: tekoja, toimintaa, sanatonta viestintää sekä lausuttuja ja lausumattomia sanoja, joilla on merkitystä työyhteisön ilmapiiriin, suoriutumiseen, työmotivaatioon ja työhyvinvointiin. Orga- 
nisaatiot kohtaavat työelämän murrokset, kuten työn pirstaloitumisen ja työkulttuurin muutokset, työnteon siirtymisen verkostoihin, teknologisen kehityksen, globalisaation ja monikulttuurisuuden sekä uudet työntekijäsukupolvet (TEM, 2014). Kuvattujen metamuutosten lisäksi organisaatioissa myllertävät lukuisat toimialakohtaiset osaamiseen ja ammattitaitovaatimuksiin liittyvät muutospaineet. Kaiken muutosvoiman keskellä ja muutosten toimeenpanijoina ovat useimmiten yritysten esimiehet, joille kasautuu siten paljon johtamisvastuuta. Ajan henki onkin nostanut esimiesvalmiuksien ja esimiestyön arvioinnin keskiöön ihmisten väliset sosiaaliset suhteet, vuorovaikutustaidot sekä vastavuoroisuuden toteutumisen esimiesten ja alaisten välisessä vuorovaikutuksessa (Wat \& Shaffer, 2005). Esimiehen hyvällä vuorovaikutusosaamisella onkin kiistaton yhteys ja myönteinen vaikutus työntekijöihin sekä organisaation toimintaan ja siten myös tuloksellisuuteen ja työhyvinvointiin (Bauer \& Erdogan, 2015; Graen \& Uhl-Bien, 1995; Liden, Sparrowe \& Wayne, 1997).

Tässä tutkimuksessa esimiestyötä lähestytään alaisen näkökulmasta ja tavoitteena on havainnollistaa esimies-alaissuhteen yksilöllistä kokemusta.

Artikkelin tavoitteet voidaan esittää seuraavien tutkimuskysymysten avulla:

1. Millaisia eroavaisuuksia alaisten kokemassa vuorovaikutussuhteessa esimiehen kanssa on?

2. Millaisia heijastumia esimiehen ja alaisen välisellä vuorovaikutuksella on kokemuksiin yksikön suoriutumisesta ja osaamisesta tai yksilön osaamisesta ja työhyvinvoinnista?

Vuorovaikutuksen laatu liittyy psykologiseen voimaantumiseen kuten tarkoituksellisuuden tunteeseen, luottamukseen omasta osaamisesta sekä vaikutusmahdollisuuksiin työn sisältöön ja työtapoihin (Manka, 2012; Viitala, 2009). Esimiehen ja alaisen hyvä vuorovaikutussuhde lisää sisäistä motivaatiota ja sosiaalista pääomaa sekä vaikuttaa yhteisöllisyyteen. Aito vuorovaikutus ei kuitenkaan synny itsestään vaan vaatii aikaa ja panostusta. Vuorovaikutustaidot liittyvät kiinteästi ihmisen persoonaan ja ihmissuhdetaitoihin (Cheetham \& Chivers, 1996, 1998). Tämä on näkymätöntä ja sisäsyntyistä osaamista, joka tulee esiin erilaisissa sosiaalisissa tilanteissa ja jota yksilö pystyy kehittämään (Gerlander \& Takala, 2000). Persoonaan ja käyttäytymiseen liittyvän osaamisen eri tekijät ovat itseluottamus, sinnikkyys, ns. jalat maassa toimiminen, tunteiden ja stressin hallinta, kuuntelutaidot, tehtäväkeskeisyys, empatiakyky, toverillisuus sekä ammatillinen käyttäytyminen (Cheetham \& Chivers, 1998).

Vuorovaikutuksesta johtamisessa ja esimiestyössä on viime aikoina puhuttu runsaasti työelämän kehittämisen näkökulmasta. Molempia teemoja on myös tutkittu paljon, mutta tutkimukset ovat painottuneet johtamiseen yleensä sekä joko suuryrityksiin (Reid \& Harris, 2002) tai startup-yrityksiin (Ariño, Ragozzino \& Reuer, 2008; Håkansson \& Waluszewski, 2013). Pienten ja keskisuurten yritysten (pk-yritykset) kontekstissa henkilöstöjohtamiseen liittyvä tutkimus on edelleen vähäistä, vaikka kyseinen sektori on merkittävä työllistäjä maassamme ja samoin sen yhteiskunnallinen merkitys on huomattava (TEM, 2014; Tilastokeskus, 2013). Pkyritysten henkilöstöjohtamisesta puuttuu usein systemaattisuus sekä järjestelmällisyys ja erityisesti esimiestyön johtamisessa on monin paikoin kehitettävää (Viitala, Kultalahti \& Kantola, 2016). Lisäksi pk-yritysten pienuus ja niiden taloudellisten resurssien rajallisuus eivät mahdollista henkilöstöjohtamiselle omaa erillistä funktiota (Dalakoura, 2009).

Artikkelissa kuvataan työntekijöiden vuorovaikutuskokemuksia esimiehen kanssa 
sekä suhteen vaikutuksia työhyvinvointiin, työmotivaatioon, yksilön ja yksikön osaamiseen sekä yksikön suoriutumiseen ja joustavuuteen. Vuorovaikutussuhteella tarkoitetaan tässä tutkimuksessa Leader-Member Exchange (LMX) -teoriaan pohjautuvaa käsitystä esimiehen ja alaisen välisestä vuorovaikutuksesta. Aineisto on kerätty 4500 vastaajalta 93 pk-yrityksestä eri toimialoilta ympäri Suomea. Tutkimus liittyy Vaasan yliopiston ja Lappeenrannan teknillisen yliopiston vuonna 2015-2016 toteuttamaan 'HERMES - Ketterä HRM digiajan pk-yrityksissä: vauhtia ja voimaa arvonluontiin' -projektiin. Seuraavassa esitellään esimies-alaissuhteen vuorovaikutukseen liittyvää kirjallisuutta ja aiempaa tutkimusta.

\section{ESIMIEHEN MERKITYS VUOROVAIKUTUSSUHTEESSA ALAISEN KANSSA}

Kirjallisuudessa vuorovaikutus käsitteenä on moniulotteinen, osin vakiintumaton ja määritelmältään puutteellinen (Tsoukas, 2009). Arkikielessä vuorovaikutus ymmärretään toiminnaksi, jossa joku on vuorovaikutuksessa toisen kanssa tai joidenkin asioiden välillä on vuorovaikutusta ja sen seurauksena yksilöt tai asiat vaikuttavat toisiinsa. Tässä tutkimuksessa vuorovaikutuksen katsotaan tarkoittavan yksilöiden välistä kielellistä tai sanatonta viestintää joko kasvokkain tai teknologiavälitteisesti sekä kohtaamiseen liittyvää reflektiivisyyttä ja tuottavaa vuoropuhelua (Tsoukas, 2009). Vuoropuheluun perustuva vuorovaikutus mahdollistaa merkitysten rakentumisen (Burleson \& Rack, 2008), tiedon välityksen (Littlejohn \& Foss, 2008) ja reflektiivisyyden (Tsoukas, 2009), pyrkimyksen tavoitteisiin, kehittymisen ja osapuolten välisen suhteen rakentumisen (Hirokawa, 2003).

Työpaikalla vietettävä aika lohkaisee ihmisen elämästä ison osan. Siksi ei ole yhden- tekevää, mitä se pitää sisällään laadullisesti ja miten sitä voidaan arvioida esimerkiksi työhyvinvoinnin ja työtyytyväisyyden kautta (Kossek, Pichler, Bodner \& Hammer, 2011). Yksi tärkeimmistä työtyytyväisyyden ja työhyvinvoinnin tekijöistä ja arviointimittareista on johtaminen ja esimiestyö (Vanroelen, Levecque \& Louckx, 2009). Koska tutkimuksemme kohdistui suomalaisten pk-yritysten henkilöstöjohtamisen tasoon, yhtenä tutkimuksen keihäänkärkenä oli työtyytyväisyyden ja työhyvinvoinnin mittaaminen esimiestyön kautta.

Johtamiskirjallisuudessa esimiestyön sisältöä ja esimieheltä vaadittavia ominaisuuksia kuvataan varsin yhdenmukaisesti ja korostetaan etenkin esimiehen valmentavaa johtamisotetta, työyhteisön osallistamista (MacLeod \& Clarke, 2009) sekä työntekijöiden ohjaamista, tukemista, palautteenantoa ja tavoitteisiin tähtäävää yhdessä tekemistä (MacLeod \& Clarke, 2009; Chênevert, Vanderberghe \& Tremblay, 2015). Näin ollen esimiestyössä korostuvat erityisesti vuorovaikutustaidot, sillä esimiehen odotetaan olevan läsnä ja viestittävän asioista aktiivisesti. Vuorovaikutusosaamisen tarvetta lisää myös se tosiasia, että postmodernin yhteiskunnan lieveilmiöt ovat tulleet myös työpaikoille: ihmissuhde-, elämäntapa-, päihde-, mielenterveys-, persoonallisuus- ja asenneongelmat sekä elämän eri kriisit (Järvinen, 2012). Tämän tutkimuksen aikana tapahtuneissa kohtaamisissa esimiehet kuvasivatkin usein oman työroolinsa laajentuneen psykologeiksi, sovittelijoiksi, arjen ongelmien ratkaisujen etsijöiksi sekä huolenpitäjiksi. Oman lukunsa esimiestyöhön tuovat myös uudet työsukupolvet, kuten esimerkiksi 1981-2000 syntyneet Y-sukupolven edustajat, jotka odottavat esimiestensä olevan heille jatkuvaa palautetta antavia valmentajia (Kultalahti, 2015). Abrahamsen (2016) kuvaakin osuvasti työelämään liittyvää vuorovaikutusta monimutkaiseksi ilmiöksi. 


\section{VUOROVAIKUTUKSEEN LITTYVÄT TEKIJ ÄT LMX- TEORIAN VALOSSA}

Vuorovaikutukseen liittyvässä tutkimuksessa huomio kiinnittyy usein yleisen tason johtamisen ja vuorovaikutuksen kokemukseen, jossa pyritään löytämään universaaleja malleja ja ratkaisuja (Fayard \& Weeks, 2005). Tässä tutkimuksessa käytetyn LMX-teorian lähtökohtana on esimiehen ja alaisen välinen yksilöllinen vuorovaikutus, joka nostaa molemminpuolisen suhteen esimiestyön keskiöön (Graen \& Uhl-Bien, 1995), on luonteeltaan hierarkkinen (Sias, 2009), ammatillinen (Hackman \& Johnson, 2009) sekä luottamukseen, kunnioitukseen ja velvollisuudentunteeseen perustuva (Sherony \& Green, 2002). LMX-teorian eli esimiehen ja alaisen välisen vaihtosuhteen teorian juuret ulottuvat vuoteen 1975, jolloin Dansereau, Graen ja Haga sekä Graen ja Cashman esittelivät sen ensi kertaa. Teorian mukaan esimies rakentaa aina omanlaisensa vuorovaikutussuhteen jokaisen alaisensa kanssa sen sijaan että esimiehellä olisi vain yhdenlainen suhde ja johtamistyyli kaikkien alaistensa kanssa (Liden \& Graen, 1980). LMX-teoria valikoitui tämän tutkimuksen viitekehykseksi, koska se on johtamiseen ja esimiestyön kehittämiseen liittyvistä keskeisistä johtajuusteoriatrendeistä ainoa, jossa huomioidaan sosiaalinen vuorovaikutus johtajan ja johdettavan välisessä kanssakäymisessä (Dihn ym., 2014; Gardner, Moss, Mahoney \& Cogliser, 2010).

LMX-teoriassa kuvataan kahdenkeskistä vuorovaikutussuhdetta, joka mahdollistaa esimiehelle yksilöllisen johtamistavan (Hodgkinson \& Ford, 2010). Onnistuneen johtamisen näkökulmasta toimivalla ja hedelmällisellä vuorovaikutuksella on osoitettu olevan vaikutusta mm. työntekijän suoriutumiseen, työyhteisötaitoihin (Gerstner \& Day, 1997; Liden, Sparrowe \& Wayne, 1997), työtyytyväisyy- teen sekä sitoutumiseen (Dulebohn, Bommer, Liden, Brouer \& Ferris, 2011). Tämän vuoksi tässä tutkimuksessa paneudutaan kokemukseen työn innostavuudesta sekä yksilötason osaamisen ja suoriutumisen hallinnan väliseen suhteeseen esimiehen kanssa käytävässä vuorovaikutuksessa. Tärkeitä tekijöitä ovat myös ihmisten yksilöllisyys, persoonallisuus sekä vuorovaikutuskyky (Nahrgang, Morgeson \& Ilies, 2009). Vuorovaikutussuhteen laatu voi poiketa hyvin paljon saman esimiehen eri alaisten välillä johtuen mainituista tekijöistä (Yukl, 2002). Arkikielessä ilmiötä voitaneen kutsua ns. henkilökemiaksi. Toisten ihmisten kanssa asiat sujuvat paremmin kuin toisten ja ihmiset tulevat eri tavoin toimeen keskenään. Siksi LMX-teoriaa kohtaan onkin esitetty myös kritiikkiä, koska se ei tunnista konfliktien vaikutusta vuorovaikutussuhteeseen, uudelleen kehittymisen mahdollisuuksiin tai suhteen rakentumiseen eri vuorovaikutuksen kehitysvaiheissa (Northouse, 2010).

LMX-teoriaan perustuen Graen ja Uhl-Bien (1995) esittävät kolmivaiheisen kehityskaaren esimiehen ja alaisen väliselle vuorovaikutussuhteelle: 1) aluksi toisilleen vieraat yksilöt pyrkivät tutustumaan toisiinsa hyödyntäen testaavia käyttäytymismalleja, 2) seuraavaksi erilaisen vuorovaikutuksen myötä syntyy tuttuuden tunne sekä sosiaalista kanssakäymistä ja 3) viimeisenä vaiheena vuorovaikutussuhteesta muodostuu kumppanuussuhde, jota yksilöllisten intressien sijaan määrittävät yhteiset intressit, kuten työn tavoitteet, organisaation oppiminen ja yrityksen strategian toteutuminen. Esimiehen ja alaisen välinen vuorovaikutussuhde ei kuitenkaan välttämättä koskaan saavuta kolmatta vaihettaan ja lukuisat vuorovaikutussuhteet voivatkin jäädä ensimmäiselle tasolleen (Graen \& Uhl-Bien, 1995). Tätä selittää LMX-teorian ydinajatus, jonka mukaan vuorovaikutus edellyttää vastavuoroisuutta ja molemminpuolista aktiivista toimintaa.

Teoria selkeyttää alaisen roolia, koska esi- 
mies ei voi yksin vastata vuorovaikutussuhteen synnystä, kehityksestä ja vaikutuksista vaan myös alaisen on otettava vastuu kehitysprosessista sekä pohdittava seuraavia kysymyksiä: kuinka realistisia ovat odotukset ja vaatimukset esimiestä kohtaan sekä miten oma toiminta ja asenne vaikuttavat vuorovaikutussuhteen kehittymiseen? Tämän vuoksi on tärkeää tunnistaa ja ymmärtää myös alaisen kokemuksia vuorovaikutussuhteesta esimieheen.

Esimies ei siis johda kaikkia alaisiaan täsmälleen samalla tavoin vaan jokaisessa vuorovaikutustilanteessa on mukana osia ihmisten käyttäytymisestä, persoonallisuudesta ja merkitysrakenteista (Schraeder \& Simpson, 2006). Koettu samankaltaisuus lisää myönteistä vaikutelmaa vastapuolesta. Siksi LMXteorian mukaan ns. piirisuhteet eli sisä- tai ulkopiiriin kuuluminen (Hackman \& Johnson, 2009) vaikuttavat vuorovaikutuksen laatuun ja sisältöön; alaiset kuuluvat joko sisäpiiriin (in-group) tai ulkopiiriin (out-group) sen perusteella, millainen vuorovaikutussuhde heillä on esimiehen kanssa ja miten heidän työroolinsa muodostuu piirisuhteen kautta. Sisäpiirin vuorovaikutus voi olla hyvin henkilökohtaisella tasolla. Siinä on sijaa luottamukselle, kunnioitukselle sekä itsenäisyydelle ja vuorovaikutus on syvällistä. Samankaltaisuuden tunne voi vahvistaa sisäpiiriin kuulumisen oikeutusta (Schraeder \& Simpson, 2006). Ulkopiirin vuorovaikutussuhde on puolestaan pinnallista, muodollista ja tiukasti toimintaan perustuvaa vuorovaikutusta vailla tunnepitoista viestintää (van Breukelen, Schyns \& Le Blanc, 2006; Hackman \& Johnson, 2009; Northouse, 2010). Northousen (2010) mukaan sisä- tai ulkopiiriin kuuluminen muotoutuu esimiehen ja alaisen välisen työskentelytavan mukaan: miten tiiviisti he työskentelevät yhdessä ja onko vuorovaikutus luontevaa ja avointa. Alaisen oma aktiivisuus kehittää sekä omaa että organisaation toimin- taa edistää sisäpiiriin pääsyä.

LMX-teorian sisä- ja ulkopiirijaottelu on saanut myös kritiikkiä. Northousen (2013) mukaan vaarana on, että esimiehet alkavat luokitella alaisiaan ja kohdella heitä eriarvoisesti. Graen ja Uhl-Bien (1995) ovat aikanaan ennakoineet tämänkaltaisen kritiikin korostamalla, että esimiehen tavoitteena tulisi aina olla hyvä vuorovaikutussuhde jokaisen alaisensa kanssa. Toisaalta teoria voi saada esimiehen ymmärtämään alitajuisten käyttäytymismallien ja ennakkoluulojen merkityksen omassa toiminnassaan ja siten kannustaa poisoppimaan epäsuotuisasta asennoitumisesta.

LMX-teoria korostaa vuorovaikutussuhteen laatua, johon sisältyy erilaisia merkityksiä ja merkitysrakenteita. Vuorovaikutuksessa ihminen tuottaa toiselle omaa totuuttaan, joka perustuu hänen omaan henkilöhistoriaan, kokemuksiin, uskomuksiin, havaintoihin sekä niiden tulkintoihin (Dixon, 1994). Merkitysrakenteet muotoutuvat ajan myötä vuorovaikutuksessa toisten kanssa muodostaen merkitysten sosiaalisen ulottuvuuden (Savery \& Duffy, 1995). Eri ammattialoilla tai työsukupolvilla voi myös olla toisistaan poikkeavat merkitysrakenteet, käsitykset ja uskomukset sekä ajattelun, päättelyn ja toiminnan logiikka (Mönkkönen \& Roos, 2010).

\section{ESIMIEHEN VUOROVAIKUTUSTAITOJEN KEHITTÄMINEN}

Esimiehen ja alaisen hyvä vuorovaikutus rakentuu monista tekijöistä. Henkilökemian lisäksi tärkeinä elementteinä vuorovaikutuksessa korostuvat molemminpuolinen kuuntelutaito, toisen näkemysten ymmärtäminen, kunnioittaminen ja arvostaminen, luottamus, yhteistoiminta, toistensa tukeminen ja yhteinen kehittyminen työhön liittyvissä asioissa, yhteinen ongelmanratkaisukyky sekä kyky 
ottaa puheeksi, käsitellä ja ratkaista hankalia asioita (Dansereau, Graen \& Haga, 1975; Graen, Novak \& Sommerkamp, 1982; Graen $\&$ Uhl-Bien, 1995). Edellä mainitut asiat olivat tutkimuksemme perusta työntekijöiden arvioidessa suhdettaan esimieheensä (ks. Liite 1).

Toimiva ja rakentava vuorovaikutus on koko työyhteisön asia ja etu; ei vain johdon ja esimiesten. Myös työntekijöillä on vastuu omasta toiminnastaan ja myönteisen ilmapiirin luomisesta (Rehnbäck \& Keskinen, 2005). Lisäksi on merkityksellistä, millainen vuorovaikutussuhde esimiehellä on omaan esimieheensä eli käytännössä yrityksen johtoon. Sillä voi olla tiedostamattomia heijastevaikutuksia esimiehen käyttäytymiseen omia alaisiaan kohtaan. Tässä tutkimuksessa on huomionarvoista, että kyselylomakkeen täyttivät myös yrityksen esimiehet. Tulosten valossa näyttää siltä, että vuorovaikutuksen laatu on melko hyvä myös johdon ja esimiesten välillä.

Järvinen $(2008,2009)$ on nostanut esiin esimiesten heikon johtamistaidon. Tutkimuksemme mukaan pk-yrityksissä on tavallista, että esimiehen asemaan edetään omasta työyhteisöstä. Johdossa ei välttämättä ole tunnistettu tarvetta uuden esimiehen johtamiskoulutukseen. Valinnan kriteerinä on voinut olla vain kokemus ja pätevyys sekä hyvät suhteet yrityksen johtoon; ei siis johtamistaito ja -valmiudet. Usein hyvä työntekijä halutaan palkita esimiestehtävällä ja kritiikittömästi unohdetaan arvioida tarvittavia johtamisominaisuuksia. Loppupäätelmissä suosittelimmekin, että pk-yrityksissä esimiestyö nostettaisiin vahvemmin kehittämisen keskiöön.

Vuorovaikutteinen esimiestyö edellyttää hyviä työkaluja ja sellaisia arviointimalleja, jotka tuottavat esimiestyöhön riittävästi tietoa. Yhtenä tällaisena työkaluna voidaan pitää Cheethamin ja Chiversin $(1996,1998)$ kehittämää työkontekstiin liittyvää kokonaisvaltaista osaamismallia, jossa yksilötason osaaminen on luokiteltu eri taustatekijöihin perustuviin ydinosaamisalueisiin. Yhtenä mallin ydinosaamisalueena on ns. persoonaan ja käyttäytymiseen liittyvä osaaminen, joka tarkoittaa kykyä omaksua sopivia, tarkoituksenmukaisia ja näkyviä käyttäytymismalleja työhön liittyvissä tilanteissa. Kyseinen ydinosaamisalue jakautuu kahteen alaluokkaan: 1) sosiaalinen / ammatillinen osaaminen (itseluottamus, motivaatio, sinnikkyys, ns. jalat maassa -toiminta, tunteiden hallinta, stressinhallinta, kuuntelutaidot, vuorovaikutustaidot, tehtäväkeskeisyys, empatiakyky) ja 2) sisäänrakennettu ammatillisuus (toverillisuus, herkkyys vertaisiaan kohtaan ja ammatillinen, normeihin mukautuva käyttäytyminen). Mallin kehittämisen aikoihin se ei juurikaan saanut vastakaikua kompetenssikirjallisuudessa, mutta työelämän monimutkaisuuden lisääntymisen myötä tilanne on muuttunut (Fernandez ym., 2012). Yksilön persoonaan ja käyttäytymiseen liittyvä osaaminen on yhdessä eettisen ja arvoihin liittyvän ydinosaamisalueen kanssa noussut mm. rekrytointiin ja kehityskeskusteluihin liittyvissä henkilöarvioinneissa merkittäväksi tekijäksi ja arvioinnin kohteeksi (Honkanen, 2005). Kuten Järvinen (2012) toteaa, lukuisat yhteiskunnan lieveilmiöt näkyvät entistä enemmän myös työpaikoilla ja vaikuttavat suoriutumiseen sekä lisäävät esimiehen työkuormaa entisestään.

Ilmapiirikyselyt ovat myös tehokas tapa saada tietoa organisaation tilasta ja kehittämistarpeista (Lönnqvist, Kujansivu \& Antikainen, 2006). Kyselyyn kannattaa sisällyttää osio vuorovaikutuksesta esimiehen kanssa, koska sen avulla saadaan arvokasta tietoa vuorovaikutuksen kokonaistasosta ja sen vaikuttavuudesta yleiseen ilmapiiriin. Tulosten perusteella on helpompaa suunnitella tarvittavaa koulutusta, valmennusta tai muita oppimiseen tähtääviä toimenpiteitä organisaatiossa. Kouluttaminen mahdollistaa oman työn tarkastelun uusista näkökulmista ja tarjoaa 
vaihtoehtoisia malleja. Erityisesti ongelmatilanteet ja havainnot huonoista ja tehottomista käytänteistä sekä toimivien työkalujen puute ongelmien ratkaisemiseksi puhuvat koulutuksen puolesta (Van Velsor, Ruderman \& McCauley, 2010).

Itsetuntemukseen perustuva sosiaalisen johtajuusosaamisen kehittäminen edellyttää koulutukselta syvällisyyttä, intensiivisyyttä, tarkkaa kohdentamista ja pitkäjänteisyyttä, koska kyseisten taitojen oppiminen ja sisäistäminen ei ole helppoa (Viitala, 2005). Koulutussisällön tulisi painottua seuraavasti: oman esimiestyön johtaminen, huomion kiinnittäminen esimiesvalmiuksiin, kuten itsetuntemus, omien vahvuuksien ja heikkouksien tunnistaminen sekä kyky oppia virheistä (Mumford, Zaccaro, Connelly \& Marks, 2000). Muita varteenotettavia, tehokkaita ja tavoitteellisia vuorovaikutustaitoja kehittäviä toimintatapoja koulutuksen ohella ovat $\mathrm{mm}$. vertaisoppiminen ja -tuki (Mäkisalo, 2003; Noro, Björkgre \& Finne-Soveri, 2002; Rempusheski, Wolfe, Dow \& Fish, 1996), mentorointi (Donovan, 1990; Juusela, Lillia \& Rinne, 2000; Nakari, Porenne, Mansukoski \& Huhtala, 2000), coaching (Whitmore, 2009), työkierto (Mäkisalo, 2003), perehdytys (Hacker, 2004; Kjelin \& Kuusisto, 2003; Robbins, 2002) sekä verkostoituminen kehittämisverkostoissa (Camp, 2000; Creuz \& Sundquist, 2002). Sellaisissa yrityksissä, joissa on erikseen henkilöstöjohtamisesta vastaavia henkilöitä tai oma HR-yksikkönsä, tulisi yhtenä toiminnallisena painopisteenä olla esimiestyön kehittäminen ja esimiesten tukeminen arjen tilanteissa.

\section{TUTKIMUKSEN TOTEUTTAMINEN}

Aineisto on kerätty yhteensä 93 pk-yrityksestä vuosina 2015-2016 joko sähköisesti tai paperilomakkeella. Yritykset edustivat laajasti eri toimialoja, kuten valmistavaa teknologiateollisuutta, kauppa, myyntiä, IT-alaa ja koulutusta. Yritysten koko vaihteli 20 työntekijästä yli 300 työntekijään. Kyselyyn osallistui yhteensä 4500 vastaajaa, joista $31 \%$ oli naisia ja 69 \% miehiä. Vastaajien ikäjakauma esitellään taulukossa 1.

Taulukko 1. Vastaajien ikäjakauma.

\begin{tabular}{|l|l|}
\hline Syntymävuosi & Vastaajien määrä \\
\hline-1950 & 100 \\
\hline $1951-1960$ & 684 \\
\hline $1961-1970$ & 1127 \\
\hline $1971-1980$ & 1117 \\
\hline $1981-1990$ & 1076 \\
\hline $1991-2000$ & 380 \\
\hline $2001-$ & 2 \\
\hline
\end{tabular}

Suurin osa eli $91 \%$ vastaajista työskenteli vakituisessa työsuhteessa, 7,5 \% määräaikaisessa työsuhteessa ja 1,5 \% vuokratyösuhteessa. Vakituisten työntekijöiden sekä vuokratyöläisten osuus oli tässä tutkimuksessa Suomen kesiarvoa hieman korkeampi. Työntekijöitä oli vastaajista $64 \%$, alempia toimihenkilöitä $19 \%$ ja ylempiä toimihenkilöitä $12 \%$. Johtoasemassa ilmoitti olevansa $4 \%$ vastaajista. Esimiesasemassa vastaajista oli $15 \%$.

Kyselyssä käsiteltiin laajasti henkilöstöjohtamiseen liittyviä teemoja ja käytänteitä. Vuorovaikutusta esimiehen kanssa selvitettiin Leader-Member Exchange (LMX) -teoriaan pohjautuvilla 12 kysymyksellä (Danserau, Graen \& Haga, 1975; Graen \& Uhl-Bien, 1995), jotka on vahvistettu LMX-UVA -kysymyksiksi (Tanskanen, Mäkelä \& Viitala, 2018) (Liite 1). Väittämiä olivat esimerkiksi "Kykenemme aidosti kuuntelemaan toistemme mielipiteitä" ja "Meidän on helppo ottaa puheeksi erilaiset työhön liittyvät asiat". Väittämiä arvioitiin asteikolla 1 (täysin eri mieltä) - 7 (täysin samaa mieltä).

Yksikkötason osaamista kartoitettiin kah- 
della kysymyksellä (Mäkelä, Viitala, Tanskanen, Uotila \& Säntti, 2013) ja yksikkötason suoriutumista kolmella väittämällä (Chiang \& Birtch, 2012; Dess \& Robinson, 1984). Yksilön osaamisen tasoa lähestyttiin arvioimalla omaa osaamista ja sen riittävyyttä (Brudan, 2010). Joustavuuden kolme kysymystä liittyivät työaikaan, työpaikkaan ja työtapoihin (Lyly-Yrjänäinen, 2013). Työn innostavuutta eli sitoutumista työhön (work engagement) mitattiin yhdeksänosaisella suomenkielisellä versiolla UWES-9 -kysymyskokonaisuudesta (Hakanen, 2009; Schaufeli, Bakker \& Salanova, 2006). Työn innostavuus käsittää kolme ulottuvuutta eli uppoutuminen, tarmokkuus ja omistautuminen. Muuttujien keskiarvot ja keskihajonnat kuvataan taulukossa 2.
Taulukko 2. Muuttujien keskiarvot ja keskihajonnat.

\begin{tabular}{|l|l|l|}
\hline Muuttuja & $\begin{array}{l}\text { Keskiarvo } \\
\text { (skaala 1-7) }\end{array}$ & $\begin{array}{l}\text { Keski- } \\
\text { hajonta }\end{array}$ \\
\hline Vuorovaikutus & 5,60 & 1,28 \\
\hline $\begin{array}{l}\text { Yksikön } \\
\text { osaaminen }\end{array}$ & 5,30 & 1,12 \\
\hline $\begin{array}{l}\text { Yksikön } \\
\text { suoriutuminen }\end{array}$ & 5,19 & 1,09 \\
\hline $\begin{array}{l}\text { Yksilön } \\
\text { osaaminen }\end{array}$ & 5,36 & 0,92 \\
\hline Joustavuus & 5,04 & 1,43 \\
\hline Tarmokkuus & 5,57 & 1,33 \\
\hline Omistautuminen & 5,55 & 1,37 \\
\hline Uppoutuminen & 5,46 & 1,38 \\
\hline $\begin{array}{l}\text { Työn imu } \\
\text { (yhteensä) }\end{array}$ & 5,53 & 1,25 \\
\hline
\end{tabular}

Taulukko 3. Eri muuttujien väliset korrelaatiokertoimet ristiintaulukoituina.

\begin{tabular}{|c|c|c|c|c|c|c|c|c|c|}
\hline & 1 & 2 & 3 & 4 & 5 & 6 & 7 & 8 & 9 \\
\hline \multirow{2}{*}{$\begin{array}{l}\text { 1. Vuorovaikutus } \\
\text { esimiehen } \\
\text { kanssa }\end{array}$} & 1 & 0,495 & 0,429 & 0,452 & 0,477 & 0,475 & 0,476 & 0,404 & 0,493 \\
\hline & & ,000 &, 000 & ,000 & ,000 & ,000 & ,000 & ,000 &, 000 \\
\hline \multirow{2}{*}{$\begin{array}{l}\text { 2. Yksikön } \\
\text { osaaminen }\end{array}$} & 0,495 & 1 & 0,693 & 0,464 & 0,382 & 0,413 & 0,435 & 0,350 & 0,43 \\
\hline & ,000 & &, 000 & ,000 & ,000 & ,000 & ,000 & ,000 &, 000 \\
\hline \multirow{2}{*}{$\begin{array}{l}\text { 3. Yksikön } \\
\text { suoriutuminen }\end{array}$} & 0,429 & 0,693 & 1 & 0,438 & 0,332 & 0,381 & 0,4 & 0,334 & 0,403 \\
\hline &, 000 & ,000 & & ,000 & ,000 & ,000 & ,000 &, 000 &, 000 \\
\hline \multirow{2}{*}{$\begin{array}{l}\begin{array}{l}\text { 4. Yksilön } \\
\text { osaaminen }\end{array} \\
\end{array}$} & 0,452 & 0,464 & 0,438 & 1 & 0,376 & 0,465 & 0,468 & 0,380 & 0,475 \\
\hline & ,000 & ,000 & ,000 & & ,000 & ,000 & ,000 & ,000 & ,000 \\
\hline \multirow{2}{*}{$\begin{array}{l}\text { 5. Joustavuus } \\
\text { työpaikalla }\end{array}$} & 0,477 & 0,382 & 0,332 & 0,376 & 1 & 0,4 & 0,407 & 0,361 & 0,423 \\
\hline &, 000 &, 000 &, 000 & ,000 & & ,000 &, 000 &, 000 &, 000 \\
\hline \multirow{2}{*}{$\begin{array}{l}\text { 6. Tarmokkuus } \\
\text { (työn imu) }\end{array}$} & 0,475 & 0,413 & 0,381 & 0,465 & 0,4 & 1 & 0,851 & 0,717 & 0,925 \\
\hline &, 000 & ,000 & ,000 & ,000 & ,000 & & ,000 & ,000 &, 000 \\
\hline \multirow{2}{*}{$\begin{array}{l}7 . \\
\text { Omistautuminen } \\
\text { (työn imu) }\end{array}$} & 0,476 & 0,435 & 0,4 & 0,468 & 0,407 & 0,851 & 1 & 0,776 & 0,947 \\
\hline & ,000 & ,000 & ,000 & ,000 & ,000 & ,000 & & ,000 & ,000 \\
\hline \multirow{2}{*}{$\begin{array}{l}8 . \\
\text { Uppoutuminen } \\
\text { (työn imu) } \\
\end{array}$} & 0,404 & 0,35 & 0,334 & 0,38 & 0,361 & 0,717 & 0,776 & 1 & 0,901 \\
\hline & ,000 & ,000 & ,000 & ,000 & ,000 & ,000 & ,000 & &, 000 \\
\hline \multirow{2}{*}{$\begin{array}{l}\text { 9. Työn imu } \\
\text { (yhteensä) }\end{array}$} & 0,493 & 0,430 & 0,403 & 0,475 & 0,423 & 0,925 & 0,947 & 0,901 & 1 \\
\hline &, 000 &, 000 &, 000 & ,000 & , 000 &, 000 &, 000 &, 000 & \\
\hline
\end{tabular}

Kaikki korrelaatiot ovat merkittäviä tasolla $p<0,01$. 
Kaikissa kysymyksissä oli käytössä seitsenportainen asteikko. Aineiston analysoinnissa hyödynnettiin yleisesti käytettyä Pearsonin intervalliasteikkoisille muuttujille soveltuvaa korrelaatioanalyysiä ja varianssianalyysiä (One-Way ANOVA) eri ryhmien eroavaisuuksien tutkimista varten. Korrelaatioanalyysillä voidaan tutkia kahden muuttujan välistä riippuvuutta. Esimerkiksi tilanteessa, jossa toinen muuttuja saa suuremman arvon, voidaan tarkastella, miten toisen muuttujan arvo käyttäytyy. Korrelaatio voi olla sekä positiivinen (kun toinen nousee, toinenkin saa korkeamman arvon) että negatiivinen (kun toinen nousee, toinen saa pienemmän arvon). Varianssianalyysillä puolestaan tutkitaan eri ryhmien, esimerkiksi eri-ikäisten, vastauksia suhteessa johonkin selittävään muuttujaan, esimerkiksi työhyvinvointiin. Post-hoc -parivertailutestillä voidaan tarkentaa, minkä ryhmien välillä eroavaisuuksia on (Karjaluoto, 2007). Tässä tutkimuksessa käytettiin Tukeyn post-hoc-testiä, joka on suosituimpia post-hoc -testejä ja soveltuu käytettävissä olevan aineiston analysointiin (ks. Field, 2009).

Taulukko 4. Eri ryhmien eroavaisuudet suhteessa esimiehen kanssa koettuun vuorovaikutukseen.

\begin{tabular}{|c|c|c|c|c|c|c|c|}
\hline \multirow[t]{2}{*}{\begin{tabular}{|l} 
Vuorovaikutus \\
esimiehen kanssa
\end{tabular}} & \multirow{2}{*}{$\begin{array}{l}\text { Keskiarvo } \\
\text { (keski- } \\
\text { hajonta) }\end{array}$} & \multirow[t]{2}{*}{ F-arvo } & \multirow[t]{2}{*}{$p$-arvo } & \multicolumn{4}{|c|}{$\begin{array}{l}\text { Tukey Post-Hoc -testi } \\
\text { (p-arvo, merkitsevät tulokset) }\end{array}$} \\
\hline & & & & 1 & 2 & 3 & 4 \\
\hline $\begin{array}{l}1 \text { Työsuhteen } \\
\text { tyyppi }\end{array}$ & & 5,960 &, 003 & & & & \\
\hline 1 Vakituinen työ & $\begin{array}{l}5,58 \\
(1,29)\end{array}$ & & & - &, 002 & & \\
\hline $\begin{array}{l}2 \text { Määräaikainen } \\
\text { työ }\end{array}$ & $\begin{array}{l}5,84 \\
(1,12)\end{array}$ & & & & - & & \\
\hline 3 Vuokratyö & $\begin{array}{l}5,64 \\
(0,99)\end{array}$ & & & & & - & \\
\hline $2 \underset{\text { yrityksessä }}{2 \text { Asema }}$ & & 21,944 &, 000 & & & & \\
\hline 1 Työntekijä & $\begin{array}{l}5,50 \\
(1,32)\end{array}$ & & & - &, 002 &, 000 &, 000 \\
\hline $\begin{array}{l}2 \text { Alempi } \\
\text { toimihenkilö }\end{array}$ & $\begin{array}{l}5,68 \\
(1,23)\end{array}$ & & &, 002 & - & & \\
\hline $\begin{array}{l}3 \text { Ylempi } \\
\text { toimihenkilö }\end{array}$ & $\begin{array}{l}5,85 \\
(1,12)\end{array}$ & & &, 000 & & - & \\
\hline $\begin{array}{c}4 \text { Johtavassa } \\
\text { asemassa }\end{array}$ & $\begin{array}{l}6,07 \\
(1,05)\end{array}$ & &, 000 &, 001 & & - & \\
\hline 3 Sukupuoli & & 11,569 &, 001 & & & & \\
\hline 1 Nainen & $\begin{array}{l}5,70 \\
(1,27)\end{array}$ & & & & & & \\
\hline 2 Mies & $\begin{array}{l}5,56 \\
(1,28)\end{array}$ & & & & & & \\
\hline 4 Esimiesasema & & 55,399 & ,000 & & & & \\
\hline 1 Kyllä & $\begin{array}{l}5,94 \\
(1,07)\end{array}$ & & & & & & \\
\hline $2 \mathrm{Ei}$ & $\begin{array}{l}5,54 \\
(1,30)\end{array}$ & & & & & & \\
\hline
\end{tabular}




\section{TULOKSET}

Aineiston analyysin ensimmäisessä vaiheessa haluttiin selvittää esimiehen kanssa koetun vuorovaikutuksen suhdetta muihin henkilöstön voimavaroihin liittyviin tekijöihin. Tulokset esitellään taulukossa 3.

Kuten voimme todeta taulukosta, esimiehen ja alaisen välinen vuorovaikutus on tilastollisesti merkittävä muiden muuttujien kanssa (yksikön osaaminen ja suoriutuminen, yksilön osaaminen, joustavuus ja työn innostavuus eri ulottuvuuksineen). Korrelaatiotasoja voidaan pitää keskisuurina (> 0,400). Näin ollen vuorovaikutus esimiehen kanssa on merkittävässä asemassa henkilöstön voimavaroja arvioivien ulottuvuuksien kanssa.

Vuorovaikutuksen yhteyksien jälkeen tutkittiin sitä, eroakko esimiehen ja alaisen välinen vuorovaikutus eri ryhmien välillä. Nämä tulokset esitellään taulukossa 4.

Taulukon mukaan käsitykset vuorovaikutuksesta esimiehen kanssa eroavat eri henkilöstöryhmien välillä. Vakituisten ja määräaikaisten työntekijöiden välillä on tilastollisesti merkittävä ero. Yllättävästi määräaikaiset työntekijät kokevat vuorovaikutuksen parempana kuin vakituiset työntekijät.

Myös asemalla on merkitystä. Työntekijät arvioivat vuorovaikutussuhteen muita heikommaksi ja erot ovat tilastollisesti merkittäviä. Toisin sanoen työntekijän asemalla on merkitystä vuorovaikutussuhteen kokemisessa. Korkeimman arvion antavat johtavassa asemassa olevat henkilöt. Alempien ja ylempien toimihenkilöiden välillä ei sen sijaan ole eroa, vaikka ylemmät toimihenkilöt arvioivat vuorovaikutussuhteen jonkin verran paremmalle tasolle kuin alemmat toimihenkilöt.

Naiset arvioivat vuorovaikutussuhteen esimiehen kanssa paremmaksi kuin miehet ja ero on tilastollisesti merkittävä. Samoin itse esimiesasemassa olevat kokevat, että heidän vuorovaikutus oman esimiehensä kanssa on parempi kuin he jotka eivät itse ole esimiesasemassa. Näiden perusteella voidaan todeta, että sukupuolella ja esimiesasemalla on niin ikään merkitystä vuorovaikutussuhteen kokemisessa.

\section{POHDINTA}

Tutkimuksen ensimmäinen ja keskeisin havainto liittyy työsuhteen tyyppiin ja työntekijän kokemukseen vuorovaikutuksen tasosta. Määräaikaisessa työsuhteessa olevat työntekijät arvioivat vuorovaikutuksen esimiehen kanssa parhaimmaksi verrattuna vakituisessa ja vuokratyösuhteessa oleviin. Löydös kertoo vuorovaikutussuhteen merkityksellisyydestä ja yksilöllisestä kokemisesta (esim. Chênevert, Vandenberghe \& Tremblay, 2015; Hodgkinson \& Ford, 2010; Macleod \& Clarke, 2009). Löydöstä voidaan pitää myös yllättävänä, sillä yritykset ovat perinteisesti investoineet vakituisten työntekijöiden perehdytykseen ja johtamiseen enemmän kuin muunlaisissa työsuhteissa työskentelevien (Allen, McManus \& Russell, 1999; Lepak \& Snell, 1999).

Cooper-Thomas ja Anderson (2006) muistuttavatkin, että etenkin perehdytyksen ja työpaikkaan sopeutumisen tutkimuksessa ovat korostuneet tyypilliset vakituiset työsuhteet, vaikka määräaikaiset työntekijät muodostavat nykyajan työelämässä yhä merkittävämmän ryhmän. Sen vuoksi myös tämän tutkimuksen löydöstä voidaan pitää mielenkiintoisena ja se osoittaa tarpeen myös epätyypillisten työsuhteiden tutkimukselle, sillä aiemmat tutkimustulokset eivät näyttäisi Cooper-Thomasin ja Andersonin (2006) eikä Benzingerinkään (2016) mukaan kuvaavan työn uusia muotoja.

Koska lopputulos esimerkiksi perehdytyksen ja sopeutumisen vaiheista esimiehen kanssa käytävän vuorovaikutuksen kokemiseen vaihtelevat monista tekijöistä riippuen (esimerkiksi perehdytysohjelmat, organisaa- 
tiokulttuuri, työnkuva, aiemmat kokemukset jne.), voi tätä tutkimustulosta vain spekuloida. Koska erilaiset työsuhteet vaativat erilaista perehdytystä (Benzinger, 2016), voi määräaikaisten työntekijöiden perehdytys olla systemaattisempaa, sillä heidän työpanoksensa ja tuottavuutensa hyödyntämiseen on käytössä vain rajallinen aika. Benzinger (2016) huomasi, että määräaikaisissa työsuhteissa perehdytysohjelma ja organisaatioon sopeutuminen oli huomattavasti yksilöllisempi prosessi kuin vakituisilla työntekijöillä, jotka osallistuivat virallisiin perehdytysohjelmiin. Määräaikaisilla työntekijöillä perehdytyksessä korostuivat mentorit, kummit ja työyhteisön tuki (Benzinger, 2016).

Määräaikaisuus voi olla myös henkilön itsensä valinta, jolloin koko työsuhdetta tarkastellaan lähtökohtaisesti myönteisessä valossa. Voi myös olla, että määräaikaisissa työsuhteissa työntekijälle annetaan heti kaikki olemassa oleva tieto sen sijaan että perehdytysohjelma olisi jatkuvampi ja pitkäkestoisempi (Van Maanen \& Schein, 1979). Benzinger (2016) huomauttaa myös, että pitkissä työsuhteissa tuottavuuden osoittaminen ja kasvu voi olla hitaampaa. Tuottavuudella sekä esimiehen ja alaisen välisellä vuorovaikutuksella onkin yhteys.

Kuten Hackman ja Johnson (2009) ovat todenneet piirisuhteiden vaikutuksesta vuorovaikutuksen laatuun ja sisältöön, sisäpiirin vuorovaikutus voi tapahtua hyvin henkilökohtaisella tasolla. Laadullisina tekijöinä Sheronyn ja Greenin (2002) mukaan toimivat luottamus, kunnioitus, velvollisuudentunne, itsenäisyys ja vuorovaikutuksen syvällisyys. Nahrgang, Morgeson ja Ilies (2009) korostavat lisäksi ihmisen yksilöllisyyttä ja persoonallisuutta sekä vuorovaikutuskykyä ylipäänsä. Voidaankin kysyä, toimiiko määräaikaisuuden aikarajoite sellaisena ajurina, joka pakottaa tai motivoi osapuolet hyötymään työsuhteesta mahdollisimman paljon sekä hyödyntämään tehokkaasti laadulliset tekijät vuorovaikutuksen rakentamisessa? Työntekijällä voi olla halu ja tarve osoittaa aktiivisesti osaamistaan ja kykyjään, jotta työsuhde jatkuisi määräajan jälkeen tai johtaisi myönteisiin suositteluihin. Toisaalta esimies voi perehdyttää määräaikaista työntekijää aktiivisemmin ja syvällisemmin yrityksen perehdytyssuunnitelman ja -käytäntöjen mukaisesti, mikäli on tiedossa, että perehdytysaika on rajallinen (Hacker, 2004; Kjelin \& Kuusisto, 2003; Robbins, 2002). Tiivis perehdytys on jo sinällään tilanne, jossa syntyy vastavuoroinen ensivaikutelma kahden tuntemattoman ihmisen kesken.

Northousen (2013) mukaan sisä- tai ulkopiiriin kuuluminen muotoutuu esimiehen ja alaisen välisen työskentelytavan mukaan. Tiivis työskentely yhdessä, avoin ja luonteva vuorovaikutus sekä työntekijän aktiivisuus työtapojen kehittämisessä ovat omiaan edistämään sisäpiiriin pääsyä. Löydöksestä herää kysymys: entä jos kaikki työsuhteet olisivat määräaikaisia? Parantaisiko se organisaatioiden ilmapiiriä vai lisäisikö se kilpailua työyhteisöjen sisällä? Kehittyisikö yritysten tuottavuus ja innovaatiotoiminta uudelle tasolle ja lisääntyisikö työpaikkojen kierto määräaikaistamalla työsuhteita? Löydöksestä voisi myös päätellä, että vakituinen työsuhde voi taannuttaa ja arkipäiväistää työnteon, käytännöt ja vuorovaikutuksen, koska tavoitteiden lisänä ei ole ns. pakottavia tekijöitä. Mahdolliset konfliktit arkipäiväistyvät tai asioita jopa lakaistaan maton alle, mistä voi organisaatiossa seurata niin sanottu vaikenemisen kulttuuri ja henkilökemioiden välinen hiljainen taistelutanner. Northousen (2010) esittämä kritiikki LMX-teoriaa kohtaan kohdistuukin juuri konfliktien merkitykseen vuorovaikutussuhteessa ja sen kehittymisessä, koska teoria ei välttämättä tunnista konfliktien roolia kyseisissä tilanteissa.

Tutkimuksessa vuorovaikutussuhteen ke- 
hittyminen saavutti Graenin ja Uhl-Bienin (1995) esittämän kehityskaaren kaksi ensimmäistä vaihetta. Eli aluksi toisilleen vieraat ihmiset tutustuvat toisiinsa ja hyödyntävät testaavia käyttäytymismalleja sekä erilaisen vuorovaikutuksen kautta siirtyvät aktiiviseen sosiaaliseen kanssakäymiseen. Sen sijaan kehityskaaren kolmas vaihe jäi tutkimuksessa osin vajaaksi eli yhteisten intressien määrittämää kumppanuussuhdetta yksilöllisten intressien sijaan ei juuri syntynyt. Syitä tähän saattoivat olla esimerkiksi yrityksen ja esimiesten työntekijöille asettamien tavoitteiden epämääräisyys tai niiden puuttuminen kokonaan (Hackman \& Johnson, 2009). Myös yritysten henkilöstölle suunnattu mahdollinen strategiaan liittyvän viestinnän puute tai osaamattomuus viestiä ymmärrettävästi saattoivat vaikeuttaa kolmannen vaiheen saavuttamista.

Vuorovaikutussuhteet erosivat myös sukupuolen ja esimiesaseman mukaan. Lisäksi työntekijän asema vaikutti vuorovaikutussuhteen kokemiseen, sillä erityisesti työntekijät arvioivat vuorovaikutussuhteen alemmalle tasolle kuin toimihenkilöt tai erityisesti johtoasemassa olevat. Tulokset antavat viitteitä siitä, että erilaiset taustatekijät vaikuttavat odotuksiin vuorovaikutussuhdetta kohtaan ja se koetaan yksilöllisesti eri tavoin. Mönkkösen ja Roosin (2010) mukaan eri ammattialoilla tai työsukupolvilla voi olla toisistaan poikkeavat merkitysrakenteet, käsitykset, uskomukset sekä ajattelun, päättelyn ja toiminnan logiikka (ks. myös Kultalahti, 2015). Näin ollen myös yrityksen sisällä hierarkian eri tasoilla olevilla saattaa olla samansuuntaisia eroavaisuuksia. Tähän puolestaan voivat vaikuttaa esimerkiksi koulutustaso ja työuran kehityskaari. Vuorovaikutussuhde on hyvin subjektiivinen kokemus ja siinä osapuolten omilla odotuksilla, käsityksillä, kokemuksilla ja tunteilla on merkittävä rooli (esim. Dixon, 1994; Savery \& Duffy, 1995).

Tuloksista käy ilmi, että korkeimman ar- vion vuorovaikutussuhteestaan esimieheen antavat johtavassa asemassa olevat. Näiden ryhmien välinen vuorovaikutus on yleensä kiinteämpää kuin vastaavasti ylemmän johdon ja työntekijöiden välinen vuorovaikutus. Northouse (2013) esittää, että ylin johto toimii esikuvana vahvistaen $\mathrm{mm}$. yrityksen arvoja ja strategisia visioita, joita esimiehet puolestaan välittävät eteenpäin organisaatiossa. Northousen (2013) kuvailema jako sisä- ja ulkopiiriin kuulumiseen voi ylimmän johdon ja esimiesten eli keskijohdon välillä suuntautua vahvasti sisäpiiriin painottuvaksi, koska vuorovaikutukseen liittyvien asioiden luonne poikkeaa esimiehen ja työntekijöiden välisistä rutiininomaisista asioista. Ylimmän johdon ja esimiesten vuorovaikutukseen voi liittyä strategisesti arkaluonteisia tai liikesalaisuuksiksi luokiteltavia asioita, joiden läpikäyminen tiivistää yhteenkuuluvuuden ja yhteisymmärryksen tunnetta ja vahvistaa merkitysrakenteita. Kuten Schraeder ja Simpson (2006) toteavat, samankaltaisuuden tunne tai yhteisten tärkeiden asioiden käsittely voi vahvistaa sisäpiiriin kuulumisen oikeutusta.

Toinen havainto on, että vuorovaikutus esimiehen kanssa korreloi työhön sitoutumisen, yksilön osaamisen sekä yksikön osaamisen, suoriutumisen ja joustavuuden kanssa. Hyvä ja toimiva vuorovaikutussuhde on siten merkityksellisessä asemassa, koska vuorovaikutus tähtää yleensä suorituksen parantamiseen ja työhyvinvoinnin ylläpitoon (esim. Dansereau, Graen \& Haga, 1975; Graen \& Uhl-Bien, 1995). Paitsi yksilön osaamisella, myös koko yksikön eli lähimmän työyhteisön myönteisillä kokemuksilla on merkitystä siihen, kuinka yksilö kokee oman työssä suoriutumisensa. Sengen (2000) mukaan hyvin toimiva yksikkö voi nostaa yksilön kokemuksia osaamisesta ja suoriutumisesta ja päinvastoin, joten myönteiseen kierteeseen voidaan päästä myös yksikön kautta. Tämä on nykyajan työelämässä hyvin tärkeä ilmiö, sillä harvoin kukaan on 
täysin yksin vastuussa työn tuloksesta vaan siihen osallistuu tavalla tai toisella ainakin lähin työyhteisö ja oma yksikkö (Podsakoff, MacKenzie, Paine \& Bachrach, 2000). Sen vuoksi myös yksikkötason tarkastelu on tärkeää.

Työn innostavuuteen liittyvät osa-alueet eli esimerkiksi tarmokkuus, omistautuminen ja uppoutuminen (kohokohtana ns. flow-tila) vaikuttavat parhaimmillaan koko työyhteisöön, jolloin mm. keskustelukulttuuri muuttuu avoimemmaksi ja toisia kannustavaksi (Hakanen, 2009; Rehnbäck \& Keskinen, 2005). Työn innostavuuden merkitystä ei voi vähätellä, sillä parhaimmillaan se saa aikaan myönteisen kehityksen, josta kaikki hyötyvät.

Vaikka tutkimus tuotti mielenkiintoisia tuloksia, on niihin kuitenkin suhtauduttava varauksella, kuten kaikessa tutkimuksessa. Tämä tutkimus hyödyntää isoa aineistoa, ja näissä tapauksissa pienetkin erot raportoituvat herkästi merkittäviksi. Tällöin tulee kiinnittää enemmän huomiota esimerkiksi korrelaatiokertoimeen kuin sen merkittävyyteen. Tässä tutkimuksessa eri muuttujien väliset korrelaatiokertoimet olivat poikkeuksetta keskisuuria (yli 0,4 mutta alle 0,5) ja niitä voidaan pitää tutkimuksen kannalta jo mielenkiintoisina. Iso aineisto mahdollistaa kuitenkin tulosten yleistyksen paremmin kuin pieni aineisto.

Tutkimuksessa on hyödynnetty valmiita mittaristoja, jotka on myös suurelta osin vahvistettu. Tämä nostaa tulosten luotettavuutta. Tämä tutkimus mittaa kuitenkin lähtökohtaisesti vastaajien käsityksiä ja kokemuksia, eikä absoluuttisia arvoja.

\section{LOPUKSI}

Kaiken kaikkiaan vuorovaikutussuhde esimiehen kanssa arvioitiin vastaajien keskuudessa melko hyvälle tasolle. Pääosin suhde omaan esimieheen oli siten henkilötasolla kunnossa, mitä voidaan pitää hyvänä lähtökohtana organisaatioiden kehittämiselle esimiestyön avulla. Kokonaisvaltaisen osaamisen näkökulmasta (Cheetham \& Chivers, 1996, 1998) näyttää siltä, että persoonaan ja käyttäytymiseen liittyvä ydinosaamisalue ja etenkin sen alaluokka, eli ihmissuhdetaidot, on entisestään korostumassa yrityksissä. Lisääntyvät ja vuosittain toistuvat ilmapiiri- ja työhyvinvointikyselyt (Lönnqvist, Kujansivu \& Antikainen, 2006) ovat omiaan edesauttamaan työntekijöiden pohdintaa (Cheetham \& Chivers, 1998) liittyen omaan työhön, työyhteisöön ja työympäristöön sekä hahmottamaan entisestään niihin liittyviä menestys- ja vaikuttavuustekijöitä.

Tutkimus osoittaa, että työpaikoilla tulisi panostaa esimiesten vuorovaikutustaitoihin; palautteenannosta vaikeiden asioiden käsittelyyn (esim. Dansereau, Graen \& Haga, 1975, Järvinen, 2008, 2009; Viitala, 2005, 2009). Tutkimuksessa havaittiin, että useat eri tekijät kuten sukupuoli, asema ja esimiesvastuu vaikuttavat siihen, miten vuorovaikutussuhde esimiehen kanssa koetaan. Kuten Viitala (2005, 2009) on tutkimuksissaan todennut, esimiehillä tulisi olla aikaa luoda yksilöllinen suhde työntekijöidensä kanssa, mutta se vaatii aikaa, tilaa ja taitoja esimiestyön suorittamiselle, jotta kaikilla työnantajaryhmillä olisi yhtäläinen mahdollisuus saavuttaa tyydyttävä ja mielekäs vuorovaikutus oman esimiehensä kanssa. Sekä yhteiskunnan että työelämän muutosten virtaukset ovat yltäneet niin merkittävästi yritysten sisälle, että laajempi keskustelu on perusteltua. Menneen ajan johtamismallit eivät enää päde ja muutokset tulisi ensin aloittaa johdon ja esimiesten välisen vuorovaikutuksen kehittämisestä. Esimiestyötäkin pitää johtaa ja tärkein tekijä siinä on viestinnän ja vuorovaikutuksen merkityksen priorisointi (Viitala, Kultalahti \& Kantola, 2016). Tämä tutkimus osoittaa myös sen, että on tärkeää tunnistaa vuorovaikutussuhteen 
taustalla olevia tekijöitä. Edelleen tutkimus osoittaa, että vuorovaikutussuhteen kokeminen on hyvin yksilöllistä eikä riitä, että eri ryhmien välillä on samanlainen suhde ja viestintä. Huomioimalla työntekijöiden erilaiset viiteryhmät ja tunnistamalla erilaiset tarpeet, päästään etenemään kohti avointa ja luottamukseen perustuvaa viestintää sekä esimiehen ja alaisen tuloksellista yhteistoimintaa.

\section{LÄHTEET}

Abrahamsen, M.H. (2016). Researching business interaction: Introducing a conceptual framework and methodology. IMP Journal, 10, 464-482.

Allen, T. D., McManus, S. E. \& Russell, J. E. A. (1999). Newcomer socialization and stress: Formal peer relationships as a source of support. Journal of Vocational Behavior, 54, 453-470.

Ariño, A., Ragozzino, R. \& Reuer, J.J. (2008). Alliance dynamics for entrepreneurial firms. Journal of Management Studies, 45, 147-168.

Bauer, T.N. \& Erdogan, B. (2015). The Oxford handbook of leader-member exchange. New York, NY: Oxford University Press.

Benzinger, D. (2016). Organizational socialization tactics and newcomer information seeking in the contingent workforce. Personnel Review, 45, 743-763.

van Breukelen, W., Schyns, B. \& Le Blanc, P. (2006). Leader-member exchange theory and research: Accomplishments and future challenges. Leadership, 2, 295-316.

Brudan, A. (2010). Rediscovering performance management: Systems, learning \& integration. Measuring Business Excellence, 14, 109-123.

Burleson, B.R. \& Rack, J. J. (2008). Constructivism theory. Teoksessa L.A. Baxter \& D. O. Braithwaite (toim.), Engaging theories in interpersonal communication. Multipleperspectives (s. 51-64). Thousand Oaks: Sage.

Camp, R. (2000). Hyvien käytäntöjen benchmarkkaus. Tie erinomaisuuteen. Laatuviesti, $16,13-15$.

Cheetham, G. \& Chivers, G. (1996). Towards a holistic model of professional competence. Journal of European Industrial Training, 20,
20-30.

Cheetham, G. \& Chivers, G. (1998). The reflective (and competent) practitioner: A model of professional competence which seeks to harmonize the reflective practitioner and competencebased approaches. Journal of European Industrial Training, 22, 267-276.

Chênevert, D., Vandenberghe, C. \& Tremblay, M. (2015). Multiple sources of support, affective commitment, and citizenship behaviors: The moderating role of passive leadership. Personnel Review, 44, 69-90.

Chiang, F. F. T. \& Birtch, T. A. (2012). The performance implications of financial and non-financial rewards: An Asian Nordic comparison. Journal of Management Studies, 49, 538-570.

Cooper-Thomas, H. D. \& Anderson, N. (2006). Organizational socialization: A new theoretical model and recommendations for future research and HRM practices in organizations. Journal of Managerial Psychology, 21, 492-516.

Creuz, K. \& Sundquist, S. (toim.) (2002). Miksi arvioida kunnan palveluja? Suomen Kuntaliitto. Helsinki: Kuntatalon paino.

Dalakoura, A. (2010). Differentiating leader and leadership development. Journal of Management Development, 29, 432-441.

Dansereau, F., Graen, G. \& Haga, W.J. (1975). A vertical dyad linkage approach to leadership within formal organizations: A longitudinal investigation of the role making process. Organizational Behavior and Human Performance, 13, 46-78.

Dess, G. G. \& Robinson, R. B. Jr. (1984). Measuring organizational performance in the absence of objective measures: The case of the privatelyheld firm and conglomerate business unit. Strategic Management Journal, 5, 265-273.

Dihn, J. E., Lord, R. G., Gardner, W. L., Meuser, J. D, Liden, R. C. \& Hu, J. (2014). Leadership theory and research in the new millennium: Current theoretical trends and changing perspectives. The Leadership Quarterly, 25, 36-62.

Dixon, N.M. (1994). The organizational learning cycle - How we can learn collectively. New York, NY: McGraw-Hill Book Company.

Donovan, J. (1990). The concept and role of mentor. Nurse Education Today, 10, 294-298.

Dulebohn, J. H., Bommer, W. H., Liden, R. C., Brouer, R. L., \& Ferris, G. R. (2011). A meta- 
analysis of antecedents and consequences of leader-member exchange: Integrating the past with an eye toward the future. Journal of Management, 38, 1715-1759.

Fayard, A. \& Weeks, J. (2005). Photocopiers and water-coolers: The affordances of interaction. INSEAD Working Paper Series: Fontaineblau.

Fernandez, N., Dory, V., SteMarie, L-G., Chaput, M., Charlin, B. \& Boucher, A. (2012). Varying conceptions of competence: An analysis of how health sciences educators define competence. Medical Education, 46, 357-365.

Field, A. (2009). Discovering statistics using SPSS. London: Sage Publications.

Gardner, W. L., Moss, T. W., Mahoney, K.T. \& Cogliser, C. C. (2010). Scholarly leadership of the study of leadership: A review of The Leadership Quarterly's second decade, 2000-2009. The Leadership Quarterly, 21, 922-958.

Gerlander, M. \& Takala, E. (2000). Viestinnän opetus interpersonaalisiin ammatteihin koulutettaessa. Teoksessa M. Valo (toim.), Nykytietoa pubeviestinnän opetuksesta (s. 156-181). Viestintätieteiden laitoksen julkaisuja 20. Jyväskylä: Jyväskylän yliopisto.

Gerstner, C. R., \& Day, D. V. (1997). Meta-analytic review of leader-member exchange theory: Correlates and construct issues. Journal of Applied Psychology, 82, 827-844.

Graen, G.B., Novak, M.A. \& Sommerkamp, P. (1982). The effects of leader-member exchange and job design on productivity and satisfaction: Testing a dual attachment model. Organizational Behavior and Human Performance, 30, 109-131.

Graen, G.B. \& Uhl-Bien, M. (1995). Relationship-based approach to leadership:

Development of leader-member exchange $(\operatorname{lmx})$ theory of leadership over 25 years: Applying a multi-level multi-domain perspective. Leadership Quarterly, 6, 219-247.

Hacker, C.A. (2004). New employee orientation: Make it pay dividends for years to come. Information Systems Managemet, 21, 89-92.

Hackman, M. Z. \& Johnson, C. E. (2009). Leadership. A communication perspective (5. painos). Long Grove, IL: Waveland Press.

Hakanen, J. (2009). Työn imun arviointimenetelmä. Työn imu -menetelmän (Utrecht Work Engagement Scale) käyttäminen, validointi ja viitetiedot Suomessa. Helsinki: Työterveyslaitos. Hirokawa, R. Y. (2003). Communication and group decision-making efficacy. Teoksessa R. Y. Hirokawa, R. S. Cathcart, L.A. Samovar \& L. D. Henman (toim.), Small group communication. Theory and practice. An anthology (s. 123-133). Oxford: Oxford University Press.

Hodgkinson, G. P. \& Ford, J. (2010). International review of industrial and

organizational psychology 25. Chichester, UK: John Wiley \& Sons.

Honkanen, H. (2005). Henkilöarvioinnin käyttö organisaatioissa. Teoksessa H. Honkanen (toim.), Henkilöarviointi työelämässä (s. 1252). Helsinki: Edita.

Håkansson, H. \& Waluszewski, A. (2013). A never ending story - interaction patterns and economic development. Industrial Marketing Management, 42, 443-454.

Juusela, T., Lillia, T. \& Rinne, J. (2000). Mentoroinnin monet kasvot. Käytännön esimerkkejä mentoroinnin sovelluksista. Yritys Kirjat. Jyväskylä: Gummerus Kirjapaino Oy.

Järvinen, P. (2008). Menestyvän työybteisön pelisä̈̈nnöt. Juva: WSOYpro.

Järvinen, P. (2009). Ammattina esimies. Juva: WSOYpro.

Järvinen, P. (2012). Esimiestyön vaikeus ja viisaus. Helsinki: Sanoma Pro Oy.

Karjaluoto, H. (2007). SPSS-opas markkinatutkijalle. Työpaperi, 344, Jyväskylä: Jyväskylän yliopisto.

Kjelin, E. \& Kuusisto, P. (2003). Tulokkaasta tuloksentekijäksi. Helsinki: Talentum Media Oy.

Kossek, E.E., Pichler, S., Bodner, T. \& Hammer, L.B. (2011). Workplace social support and work-family conflict: A meta-analysis clarifying the influence of general and work-familyspecific supervisor and organizational support. Personnel Psychology, 64, 289-313.

Kultalahti, S. (2015). "It's so nice to be at work!" Adopting different perspectives in understanding Generation $Y$ at work. Väitöskirja. Vaasan yliopisto. Acta Wasaensia 339.

Lepak, D. P. \& Snell, S. A. (1999). The human resource architecture: Toward a theory of human capital allocation and development. Academy of Management Review, 24, 31-48.

Liden, R. C. \& Graen, G. (1980). Generalizability of the vertical dyad linkage model of leadership. 
Academy of Management Journal, 23, 451-465. Liden, R.C., Sparrowe, R.T. \& Wayne, S.J. (1997). Leader-member exchange theory: The past and potential for the future. Research in Personnel and Human Resource Management, 15, 47-119.

Littlejohn, S. W. \& Foss, K.A. (2008). Theories of buman communication. (9. painos). Belmont: Thomson Wadsworth.

Lyly-Yrjänäinen, M. (2013). Työolobarometri. Syksy 2012. Ennakkotietoja. TEM raportteja 6/2013. Työllisyys- ja yrittäjäosasto. Työelämän osaaminen ja laatu -ryhmä. Helsinki: Työ- ja elinkeinoministeriö.

Lönnqvist, A., Kujansivu, P., Antikainen, R. (2006). Suorituskyvyn mittaaminen - Tunnusluvut asiantuntijaorganisaation johtamisvälineenä. (2. uudistettu painos). Helsinki: Edita Publishing Oy.

van Maanen, J. \& Schein, E. H. (1979). Toward a theory of organizational socialization. Research in Organizational Behavior, 1, 209-264.

Manka, M-L. (2012). Työn ilo. (3. painos). Helsinki: WSOYpro Oy.

MacLeod, D. \& Clarke, N. (2009). Engaging for success: Enhancing performance through employee engagement: A report to government. Surrey: Office of Public Sector Information.

Mumford, M. D., Zaccaro, S. J., Connelly, M. S. \& Marks, M. A. (2000).

Leadership skills: Conclusions and future directions. Leadership Quarterly, 11, 11-35.

Mäkelä, L., Viitala, R., Tanskanen, J., Uotila, T-P. \& Säntti, R. (2013). Lähijobtamisen kehittämiselläparempaa työhyvinvointia ja tuloksellisuutta. Vaasan yliopiston julkaisuja. Selvityksiä ja raportteja 191. Vaasa: Vaasan yliopisto.

Mäkisalo, M. (2003). Yhdessä onnistumme. Opas työyhteisön kehittämiseen ja hyvinvointiin. Tampere: Tammer-Paino Oy.

Mönkkönen, K. \& Roos, S. (2010). Työyhteisötaidot. Kuopio: Unipress.

Nahrgang, J. D., Morgeson, F. P. \& Ilies, E. (2009). The development of leader-member exchanges: Exploring how personality and performance influence leader and member relationships over time. Organizational Behavior and Human Decision Processes, 108, 256-266.

Nakari, L., Porenne, P., Mansukoski, S. \& Huhtala, T. (1998). Mentorointi. Johdon ja asiantuntijoiden kehitysmenetelmä. Helsinki: Ekonomia Oy.
Noro, A., Björgren, M. \& Finne-Soveri, H. (2002). Mitä on vertailukehittäminen. RAI:n laitoshoidon johtamisen näkökulmasta. Sairaanhoitaja, 75, 23-37.

Northouse, P.G. (2010). Leadership. Theory and practice. (5. painos). London: Sage.

Oxford Advanced Learners Dictionary (2015). Haettu 26.6.2018 osoitteesta www.oxforddictionaries.com/definition/learner/interaction.

Podsakoff, P., MacKenzie, S., Paine, J. \& Bachrach, D. (2000). Organizational citizenship behaviors: A critical review of the theoretical and empirical literature and suggestions for future research. Journal of Management, 26, 513-563.

Rehnbäck, K. \& Keskinen, S. (2005). Työhyvinvointia alaistaidoilla ja esimiestyön hallinnalla. Helsinki: Kuntien eläkevakuutus.

Reid, R.S. \& Harris, R.I.D. (2002). The determinants of training in SMEs in Northern Ireland. Education and Training, 44, 443-450.

Rempusheski, V.F., Wolfe, B.E., Dow, K.H. \& Fish, L.C. (1996). Peer review by nursing research committees in hospital. The Journal of Nursing Scholarship, 28, 51-53.

Robbins, R.L. (2002). Orientation: Necessity or nightmare? Supervision, 63, 8-10.

Savery, J.R. \& Duffy, T. M. (1995). Problem based learning: An instructional model and its constructivist framework. Educational Techno$\log y, 35,31-38$.

Schaufeli, W., Bakker, A. B. \& Salanova, M. (2006). The measurement of work engagement with a short questionnaire: A cross-national study. Educational and Psychological Measurement, 66, 701-716.

Schraeder, M. \& Simpson, J. (2006). How similarity and liking affect performance appraisals. Journal of 2uality and Participation, 29, 34-40.

Sherony, K. M. \& Green, S. G. (2002). Coworker exchange: Relationship between coworkers, leader-member exchange, and work attitudes. Journal of Applied Psychology, 87, 542-548.

Senge, P. M. (2000). Reflection on “a leader's new work: Building learning organizations. Teoksessa D. Morey, M. T. Maybury \& B. Thuraisingham (toim.), Knowledge management: Classic and contemporary works (s. 53-60). Cambridge: MIT Press.

Sias, P. M. (2009). Organizing relationship. Traditional and emerging perspectives on workplace 
relationships. Thousand Oaks, CA: Sage.

Tanskanen, J., Mäkelä, L. \& Viitala, R. (2018). Linking managerial coaching and leadermember exchange on work engagement and performance. Journal of Happiness Studies. Ennakkojulkaisu verkossa. doi: https://doi. org/10.1007/s10902-018-9996-9

Tsoukas, H. (2009). A dialogical approach to the creation of new knowledge in organizations. Organization Science, 20, 941-957.

Tilastokeskus. (2013). Haettu 25.1.2018 osoitteesta https://www.stat.fi/index en.html

Työ- ja elinkeinoministeriö. (2014). Haettu 25.1.2018 osoitteesta http://tem.fi/en/frontpage

Vanroelen, C., Levecque, K. \& Louckx, F. (2009). Psychosocial working conditions and selfreported health in a representative sample of wage-earners: A test of the different hypotheses of the demand-control-support-model. Occupational Environmental Health, 82, 329-342. van Velsor, E., Ruderman, M. \& McCauley, C. (2010). Afterword. Teoksessa The center for creative leadership. Hoboken: Jossey-Bass.
Wat, D. \& Shaffer, M.A. (2005). Equity and relationship quality influences on organizational citizenship behaviors: The mediating role of trust in the supervisor and empowerment. Personnel Review, 34, 406-422.

Viitala, R. (2005).Johda osaamista! Keuruu: Otavan Kirjapaino Oy.

Viitala, R. (2009). Henkilöstöjobtaminen. Strateginen kilpailutekijä. (1.-2. painos). Helsinki: Edita.

Viitala, R. Kultalahti, S. \& Kantola, J. (toim.). (2016). Henkilöstöjohtamisen tila, tarpeet ja tulosvaikutukset pk-yrityksissä. Työsuojelurahaston hankkeen nro 114136 loppuraportti. Vaasan yliopiston julkaisuja. Selvityksiä ja raportteja 211. Vaasa: Vaasan yliopisto.

Whitmore, J. (2009). Growing human potential and purpose. The principle and practice of coaching and leadership. London: Nicholas Brealey Publishing.

Yukl, G. (2002).Leadership in organizations. New Jersey: Prentice Hall. 


\section{LIITE 1}

Esimiehen ja alaisen välinen vuorovaikutussuhdemittaristo

1. Tulemme hyvin toimeen esimieheni kanssa

2. Esimieheni tukee virheiden ja ongelmien rakentavaa käsittelyä työyhteisössämme

3. Yhteistoimintamme edesauttaa meidän kummankin työtehtävien suorittamista

4. Voimme käsitellä avoimesti hankalatkin asiat toistemme kanssa

5. Luotamme toisiimme

6. Arvostamme toistemme osaamista työssä

7. Kykenemme aidosti kuuntelemaan toistemme mielipiteitä

8. Haluamme yleensä ymmärtää toisiamme

9. Kunnioitamme toistemme mielipiteitä, vaikka emme olisikaan samaa mieltä asioista

10. Pystymme molemmat tukemaan toisiamme kehittymään työssä

11. Tarpeen tullen asetumme tukemaan toinen toisemme näkemyksiä työhön liittyvissä asioissa

12. Meidän on keskenämme helppo ottaa puheeksi erilaiset työhön liittyvät asiat 


\section{INTERACTION BETWEEN SUPERVISOR AND EMPLOYEE - REFLECTIONS ON CHANGING WORKING LIFE}

Riitta Forsten-Astikainen, University of Oulu, Kerttu Saalasti Institute, Micro-Entrepreneurship Centre of Excellence MicroENTRE

Susanna Kultalahti, University of Vaasa, School of Management, Human Resource Management

The ongoing change in working life and work requires more interaction skills; jobs are fragmented and transferred to networks, digitalization, and diversity induced by multiculturalism and a new generation of employees, and the former know-how face significant pressures of change. Supervisors particularly play an important role in organizations, and in their interaction capability especially is a key factor in changes concerning everyday working life, maintaing employee productivity and motivation, and developing positive wellbeing and atmosphere at work.

The article examines the experiences of interaction with the supervisor in different groups of employees and the implications for job sufficiency, competencies of the individual and the unit, and also for the unit performance and flexibility. This study is based on the LMX theory of the relationship between superiors and subordinates. The data was collected from 4500 respondents in 93 SMEs in various industries around Finland and analyzed quantitatively. The research is affiliated with the HERMES project implemented in 2015 and 2016 by the University of Vaasa and the Lappeenranta University of Technology.

The most important observation of the study is related to the type of employment and the quality of interaction experienced by the employee. The estimation of fixed-term employees on the interaction with their supervisor was higher than that of permanent or temporary workers. This finding is surprising and shows the significance and unique experience of the relationship. Interaction relations also differed in respect of gender and leadership position. In addition, the position of employee influenced interaction relations.

Keywords: competence, interaction, interactive management, LMX theory, superior work, type of employment 